\title{
福山米酢の仕込み時に行われる振り䊁の 役割についで
}

\author{
小泉幸道*・鈴木忠邦*・中山利夫* \\ 橋口和典 ${ }^{* *} \cdot$ 柳田藤治 ${ }^{*}$
}

\author{
Role of Floating Koji Added on the Surface of Newly Prepared \\ Mash for Fukuyama Rice Vinegar Production \\ (Studies on the Pot Vinegar Part II) \\ Yukimichi KoIzumi*, Tadakuni Suzuki ${ }^{*}$, Toshio Nakayama*, \\ Kazunori HashiguCHI ${ }^{* *}$ and Fujiharu YanAGIDA ${ }^{*}$ \\ * Department of Brewing and Fermentation, Tokyo University of Agriculture, \\ 1-1, Sakuragaoka 1-chome, Setagaya-ku, Tokyo 156 \\ **Sakamoto Jyozo Co. Ltd., 3499 Fukuyama, Fukuyama-cho, \\ Aira-gun, Kagoshima 899-45
}

\begin{abstract}
The role of floating rice koji in the manufacture of pot vinegar was investigated using the mash prepared on an industrial scale at Fukuyama, Kagoshima Prefecture. The results were as follows: (1) Effects of the addition of floating rice koji: without addition of floating rice koji,alcohol fermentation occurred significantly at the early stage and delayed the start of acetic acid fermentation, resulting in the prolongation of the fermentation period. These results revealed that surplus alcohol content hindered acetic acid fermentation even in the presence of acetic acid bacteria. (2) Effects on the formation of organic acids except acetic acid: lactic acid was the most dominant in both samples. The amount of lactic acid produced was high in the pot vinegar added with floating rice koji. The other acids detected were succinic, pyroglutamic, pyruvic and malic acids. (3) Effects of the time of adding floating rice koji : delayed addition of floating rice koji onto the mash caused higher level of alcohol production, resulting in the reduction of acetic acid fermentation. (4) Effect of the addition of starters including yeast immediately after the mash preparation : addition of a high inoculum size of yeast cells resulted in a high production of alcohol and hindered the acetic acid fermentation. Addition of acetic acid bacteria after alcohol fermentation without the addition of yeast showed no significant difference from the sample without the addition of acetic acid bacteria. From these results, it was revealed that addition of floating rice koji immediately after the preparation of mash in the manufacture of pot vinegar, played an important role to help smooth acetic acid fermentation after alcohol fermentation.
\end{abstract}

(Received Jul. 7. 1988)

†畺酢に関する研究（第 2 報）（前報，文献 3)）

“東京農業大学酮造学科（テ156 東京都世田谷区桜丘 1-1-1）

** 坂元酸造株式会社（テ899-45 鹿児島県姶良郡福山町福山 3499） 
黒酢や黒畐酢等の商品名で市販されている食酢は, 普 通の食酢製法ではなく，醸造用罴を用いて蒸米之米靝之 水を入れて，恵まれた南国の太陽を浴びながら，自然発 醉で行われ，約 3 力月の発醭期間中に，糖化・アルコー ル発酵・酶酸発酵の三つの過程が，この賣の中で行われ， 半年から一年間の熟成期間を経て，天然䤁造されたもの である．䓌酢の製法等については，東 ${ }^{122}$ や著者あ前 報》で説明したが，製法の一つに仕込み直後または翌日 に，乾燥した胞子の多い老称た趃を盇の上面に撒く操作 がありこれを振り麹と称している。この振り数は，ア ルコール発酵後は自然に落下して，次に液表面に酢酸菌 膜が張り，酢酸発醉が行われる.

本研究は壳酢製造において，伝統的に行われている振 り翅の役割を究明することにあり，前報引において $5 l$ の小盇を用いて研究室規模で各種試験を行ったところ， 振り教を行わないとアルコール生成が早く，その生成量 あ多いことより，以後の酷酸発醅が順調に行われないこ とを報告した．本報ではこれらを儫付ける意味も含めて， 実際に㯰酢の製造を行っている，鹿児島県姶良郡で前 報32 と同様に，振り教に関連した各種条件下で実験を行 い，それらが発醉へ及ぼす影響について検討した。

\section{実 験 方 法}

\section{1. 標準仕込み配合}

髙酢の仕込みは，鹿児島県姶良郡福山町福山の，坂元 醇造(株)にて行った，容器は薩摩焼の盇で, 直径 42 $\mathrm{cm}$, 口径 $14 \mathrm{~cm}$, 高さ $60 \mathrm{~cm}$, 内容量 $54 \mathrm{l}$ の盇を使 用した，標準仕込み配合は，蒸米（93\% 精米步合）8.3 $\mathrm{kg}$ ，米趎（水分約 $28 \%$ ） $3.0 \mathrm{~kg}$ ，水 $30 l$ で仕込みを行 い，翌日；振り鞄として米翅の $10 \%$ にあたる $0.3 \mathrm{~kg}$ （水分約 20\%）を，蒸米之米䞶が液面に浮いている上に，

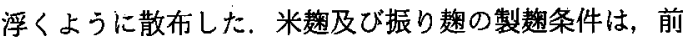
報了と同様に行った。

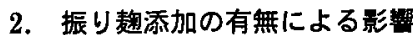

振り趃の役割を究明するにあたり，振り靝添加の有無 が発醭へ及ぼす影響について検討した，仕込み配合は， 振り趃仕込みについては標準仕込みで行い，振り趜無し は仕込み時に米䞶を $3.3 \mathrm{~kg}$ 使用した。

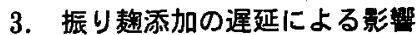

仕込み直後または翌日に散布される振り䞤を，仕込み 5 日と 10 日目に行い，発醉への影響について検討した。

\section{4. 振り甥の代替として発泡スチロール板を用いての} 影繁

振り数の代替として, 厚さ $7 \mathrm{~mm}$ の発泡スチロール
板を表面に浮かせて発醉を行い，振り靝と比較した，仕 込み配合は振り数無し之同様に行い，発泡スチロール板 は，発酵期間中全て浮幼たすのと，酶酸発醉への影響 をみるために，仕込み後 20 日目に取り除いたものにつ いて，発醉への影響について検討した。

\section{5. 微生物添加による影暗}

夁酢製造においては，微生物の添加はほとんど行われ ていないのが多い，このため声の中にはアルコール及び 酷酸発醉が行われないのも少なからず認められている. そこで正常発醉を目的に，振り静を行いながら前報引に 準じ，仕込み時に酵母 (Saccharomyces cerevisiae) を $10^{3} / \mathrm{ml}$ と $10^{5} / \mathrm{ml}$ ，また醉母無添加でアルコール発 醉を行わせ，仕込み後 20 日目に酷酸菌（Acetobacter aceti）を $10^{5} / \mathrm{m} l$ それ゙れ添加して，発醉への影響に ついて検討した。

\section{6. 成分分析及び微生物測定}

㽦酷発醉中の成分分析及び微生物測定は，前報”之同 様に行った。但し，試料の採取籄所は表面下 $15 \mathrm{~cm}$ と した.

\section{7. 有機酸分析}

㯰酢発酵中の有機酸分析は，経日的に行った．酢酸が 他の有機酸分析に支障をきたすので，試料は水蒸気蒸留 を行い，酷酸を除去した後，有機酸量を適宜稀釈して， 盛進有機酸分析計 (S-500 型) にて分析を行った。

\section{実験䊅果及ひ考察}

\section{1. 振り敂添加の有無による影䈏}

振り楼添加の有無による発醉への影響について，経日 的な成分分析と微生物測定結果を Table 1 に示した。 振り麭を行ったものは，アルコール生成は 15 日目で $5.5 \% ， 20$ 日目で $7.6 \%$ を生成した．乳酸菌数は仕込み 1 日目で既に $10^{6} / \mathrm{m} l$ 検出されており，20日目迄は $10^{8}$ $\sim 10^{9} / \mathrm{ml}$ であった．仕込み初期に乳酸菌が多いのは， 趎中に含まれている乳酸菌が，糖化作用之共に增殖した ものと思われる．このように乳酸菌によって生成された 乳酸で $\mathrm{pH}$ が下がり, 酒の場合と同様に炼菌による污 染を少なくして，順調にアルコール発醉を行わせている 之思われる．尚，乳酸量については有機酭の項で述べる. 乳酸菌は20日目以降減少した。面の蒸米と振り麹は， 30 日目以降徐々に落下し，液面には酢酸菌膜か張り出 し, 酶酸発醅が開始された。 このため，醉母も減少した。 酸生成は 45 日目で $2.2 \% ， 90$ 日目で $5.5 \%$ 之順調に酢 酸発醉は行われた。この時の酷酸菌数は 30 日目で $10^{6}$ / $\mathrm{m} l, 45$ 日目で $10^{8} / \mathrm{m} l$ で以後徐々に減少した. 
Table 1 Effects of the addition of floating koji on the chemical components and microbial counts during rice vinegar manufacturing process in a pot

\begin{tabular}{|c|c|c|c|c|c|c|c|}
\hline \multirow{2}{*}{ Sample } & \multirow{2}{*}{$\begin{array}{l}\text { Fermentation } \\
\text { period (days) }\end{array}$} & \multicolumn{3}{|c|}{ Chemical components } & \multicolumn{3}{|c|}{ Microbial count (viable cells $/ \mathrm{m} l$ ) } \\
\hline & & $\mathrm{pH}$ & $\operatorname{Acid}(\%)^{*}$ & Ethanol $(\%)$ & $\begin{array}{l}\text { Lactic acid } \\
\text { bacteria }\end{array}$ & Yeast & $\begin{array}{l}\text { Acetic acid } \\
\text { bacteria }\end{array}$ \\
\hline \multirow{7}{*}{$\begin{array}{l}\text { Added with } \\
\text { floating koji }\end{array}$} & 10 & 3.50 & 0.99 & $1 . \overline{38}$ & $1.2 \times 10^{9}$ & $1.3 \times 10^{4}$ & $2.6 \times 10^{2}$ \\
\hline & 15 & 3.23 & 1.21 & 5.47 & $2.3 \times 10^{9}$ & $3.4 \times 10^{7}$ & $1.5 \times 10^{3}$ \\
\hline & 20 & 3. 22 & 1.21 & 7.64 & $5.1 \times 10^{8}$ & $5.6 \times 10^{5}$ & $1.2 \times 10^{4}$ \\
\hline & 30 & 3.18 & 1.30 & 6.94 & $1.4 \times 10^{6}$ & $5.5 \times 10^{3}$ & $2.5 \times 10^{6}$ \\
\hline & 45 & 3. 26 & 2. 24 & 5.71 & $2.3 \times 10^{3}$ & $<10$ & $4.0 \times 10^{8}$ \\
\hline & 60 & 3.23 & 3.70 & 4.95 & $<10$ & $<10$ & $1.0 \times 10^{6}$ \\
\hline & 90 & 3. 15 & 5.45 & 1.05 & - & - & $3.9 \times 10^{3}$ \\
\hline \multirow{7}{*}{$\begin{array}{l}\text { Not added with } \\
\text { floating koji }\end{array}$} & 10 & 3.37 & 0.81 & 7. 72 & $5.9 \times 10^{7}$ & $3.9 \times 10^{8}$ & $2.0 \times 10^{1}$ \\
\hline & 15 & 3.23 & 0.97 & 8.50 & 4. $3 \times 10^{8}$ & $1.3 \times 10^{8}$ & $1.8 \times 10^{2}$ \\
\hline & 20 & 3.38 & 1.05 & 8. 36 & $2.4 \times 10^{7}$ & $8.8 \times 10^{6}$ & $6.5 \times 10^{3}$ \\
\hline & 30 & 3.35 & 1.18 & 7.82 & $7.6 \times 10^{5}$ & $1.4 \times 10^{4}$ & $2.7 \times 10^{5}$ \\
\hline & 60 & 3. 30 & 2.80 & 5.70 & $<10$ & $<10$ & $2.0 \times 10^{8}$ \\
\hline & 90 & 3.18 & 4. 52 & 1.92 & - & - & $1.6 \times 10^{6}$ \\
\hline & 120 & 3.13 & 5. 36 & 0.74 & - & - & $2.7 \times 10^{3}$ \\
\hline
\end{tabular}

* as acetic acid

次に振り数無しでは，アルコール生成は 10 日目で 7.7\%，15日目で $8.5 \%$ を生成した。これを振り麹有り と比較すると，10日目で $6.3 \%$ 多く生成した.このよ うに振り翅無しでアルコールが多く生成するのは，前報 と同椂に振り数有りの上面は，蒸米と米娄は浮き上が り，その上は乾燥した振り粷で覆われているため，上面 はある程度空気を遮断しているのに対して，振り数無し では蒸米上米趋は浮き上がるが，振りが無いために液 面と空気が接触している面が大きいことより，酵母の増 殖 $10 /{ }^{8} \mathrm{~m} l$ と多く，このためにアルコールが多く生成 されたものと思われる.酸生成は 60 日目で $2.8 \%$ であ った.これを振り教有りと比較すると約 $1 \%$ 少なく，ア ルコール濃度が高かったために，酢酸発酵の開始が遅れ たものと思われる。従って酢酸発酵は，120日目の 5.4 \%をむって終了した．振り敖有りと比較すると，約 1 カ月遅かった。

前報”において， $5 l$ の小盇を用いて研究室規模で， 振り敖添加の有無による発酵への影幚について検討した ところ，振り趐を行ったものはアルコール生成は，10 日目で $5.5 \%$ ，20 日目は $6.8 \%$ ，酸生成は 30 日目で 3.5 \%，40日目は 5.6\%であった。次に振り趐無しではア ルコール生成は, 10 日目で 7.5\%, 酸生成は 30 日目で 2.6\%，40日目は 4.5\%であった。このように振り数無
しではアルコール生成は早く，その生成量す多く以後の 酢酸発醉の開始が遅れることを報告したが，本実験より 実際の婊酷製造においても同様の結果を示したことより， 仕込み直後に行われる振り敖は，急激なアルコール生成 を抑え, 以後の酢酸発醉を順調に行わせていることが明 らかとなった。 また前報”では振り整が無いと，仕込み 初期の上面は蒸米と米敖が浮いており，この部分に種々 のカビや産膜酵母が生え易いことを報告したが, 本実験 においても同様の結果を示し，特にカビの繁殖が多かっ た.これらが発酵や製品へ及ぼす影響はきわめて大きい と思われ，微生物の混入防止の意味からも，振り趐は必 要と思われた。

\section{2. 振り靝添加の有無による有機酸の影䇺}

振り埸添加の有無による，酢酸以外の有機酸について， その経日的变化を Table 2 に示した，仕闸み初期 10 日 目迄は，乳酸とコハク酸が検出された，20日目の乳酸 量は, 振り懒有りは $1100 \mathrm{mg} / 100 \mathrm{ml}$, 振り敖無しで は $920 \mathrm{mg} / 100 \mathrm{ml}$ であった、振り靝を行うことにより 乳酸が多く検出されるのは，前述のように賿上面は，あ る程度空気を遮断しているので乳酸菌数が多く，同時に 急激なアルコール生成が行われないこと等によるもの上 思われる。乳酸は酢酸発酵が行われる 30 日目以降大き く娍少するが、これは酢酸菌により，乳酸から「むれ香」 
Table 2 Effects of the addition of floating koji on the production of organic acids during rice vinegar manufacturing process in a pot

\begin{tabular}{lrrrrrrrrrrrrrr}
\hline \hline & \multicolumn{10}{c}{ Fermentation period (days) } \\
\cline { 2 - 14 } Organic acids & \multicolumn{1}{c}{10} & \multicolumn{1}{c}{20} & \multicolumn{1}{c}{30} & & 60 & & 90 & & 120 \\
\cline { 2 - 14 } & A & B & A & B & A & B & A & B & A & B & A & B \\
\hline Lactic acid & 845 & 708 & 1100 & 920 & 1043 & 870 & 742 & 687 & 623 & 540 & 584 & 508 \\
Succinic acid & 31 & 45 & 40 & 47 & 49 & 46 & 30 & 34 & 27 & 32 & 24 & 34 \\
Pyroglutamic acid & - & - & - & - & 21 & 25 & 27 & 30 & 35 & 37 & 44 & 45 \\
Pyruvic acid & - & - & 3 & 4 & 4 & 4 & 4 & 5 & 4 & 5 & 4 & 4 \\
Malic acid & - & - & 4 & 4 & 3 & 4 & 4 & 4 & - & - & - & - \\
\hline
\end{tabular}

The numerical values are expressed as $\mathrm{mg}$ per $100 \mathrm{ml}$.

A : Added with floating koji B : Not added with floating koji

と称する不快臭であるアセトインが生成され，その一部 はさらに酸化されてジアセチルを生成しているすのと思

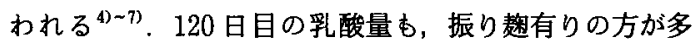
かった．普通の市販米酢の乳酸量の平均値 ${ }^{899)}$ は, 20.3 $\mathrm{mg} / 100 \mathrm{ml}$ なのでそれよりもはるかに多い. 製法や発 醉状態が普通の食酢製造とは異なるので，このように多 くの乳酸が生成されるむのと思われる. 次いで多い有機 酸はコハク酸であるが，30日目以降減少した。 ピログ ルタミン酸は 30 日目より検出され，120日目迄徐々に 増加した．ピログルタミン酸は，原料中に含まれている タンパク質からグルタミン酸が遊離し，さらに酸性条件 下でピロ化したるのと思われる.この他にピルビン酸, リンゴ酸が僅かに検出された。 円谷ら ${ }^{(0)}$ は福山米酢の 酸造工程中の有機酸の变化について報告しているが，著 者らと㑯向は同じであるが，その含量は本実験の方が全 体的に多功た。

\section{3. 振り趣添加の遲延による影整}

仕込み直後または翌日に行われる振り趐を，仕込み 5 日及び 10 日目にその散布を遅らせた時の, 発酵への影 響について検討した．経日的なアルコールと酸生成の結 果を，Fig. 1 に示した．振り錮を仕込み 1 日目に行っ た通常仕込みにおいては，10日目のアルコールは $1.1 \%$, 20 日目では $7.7 \%$ を生成し, 以後酷酸発酵と共にアル コールは減少し，60日目の酸は $3.6 \% ， 90$ 日目では 5.1 \%を生成した，通常仕込みにおいては，順調にアルコ 一ル及び酢酸発醉は行わ机た。

次に振り教を仕込み 5 日目に行ったものは，10日目 のアルコールは $5.2 \%$ でその生成は早く，20日目では $8.1 \%$ を生成した。 以後酶酸発醉と共に減少し，60日目 の酸は $2.4 \% ， 90$ 日目では $4.8 \%$ を生成した。こてを通
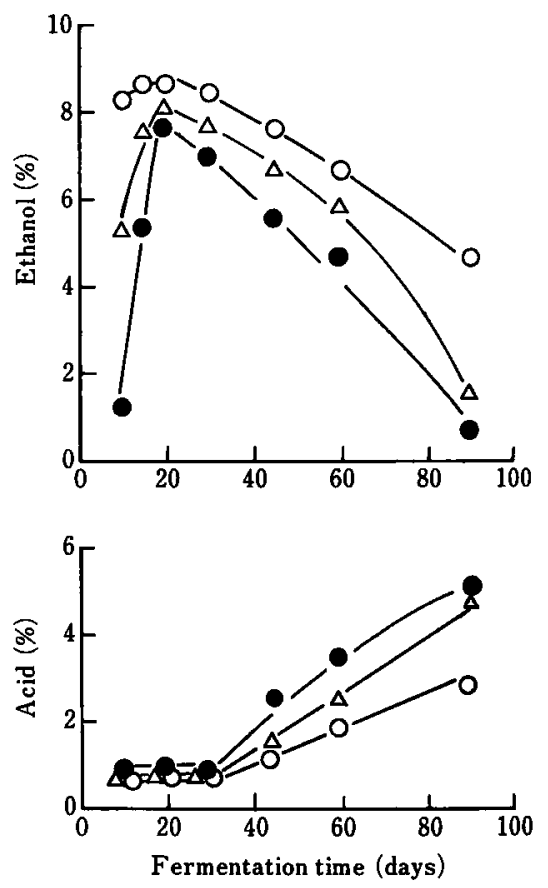

Fig. 1 Effects of the time of adding floating koji on the production of ethanol and acid during rice vinegar manufacturing process in a pot

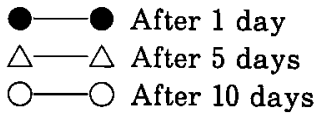

常仕込みと比较すると，酸の立ち上がりは荤かったが， 90 日目の酸生成は大差なかった。 しかし仕込み 10 日目 に振り趐を行ったものは，10日目でアルコールは $8.2 \%$ 
を生成し，他の仕込み条件より生成量は多く，15日目 では 9\%近く迄達した。 30 日目以降アルコールは徐々 に減少しているが，アルコールが高いために酷酸発醉は 弱く，60日目で $1.9 \% ， 90$ 日目では $2.9 \%$ の生成であ った．仕込み後，振り趋の散布が遅くなる程アルコール 生成は多くなるが，前述の振り䞤無しと同様に酵母の增 殖か活発になりここような結果になったものと思われ る. 前報)において $5 l$ の小荲を用いて，研究室規模で 同様の実験を行ったところ，振り趋を仕込み後 1 及び 3 日目に行ったものは，アルコール及び酢酸発醉は順調に 行われたが，振り趋を仕込み後 5 及び 10 日目に行った あのは，10日目でアルコールは8.0 8.3\%，20日目で は $9 \%$ 近く迄達し，以後の酶酸発醉は行われなかったこ とを報告した．が本実験より実際の夁酢製造においても 同様の結果を示したことより，急激なアルコール生成を 抑えることと，前述の上面にカビや産膜醉母等を繁殖さ せないようにするには，振り静は仕込み初期に行う必要 が明らかとなった。

\section{4. 振り樍の代替として発泡スチロール板を用いての} 影睡

量酷製造において，振り靝や蒸米等は仕込み後 40 日 目以胮加徐々に落下して, 液面には酶酸菌膜が增殖し て酷酸発醉が行われるが，多くの㽦の中にはアルコール 発醉が終了しても，振り趎や蒸米等は落下しないことも あり，従って酢酸発醅が行われない㽦す見うけられる。 ここではこれらを裹付ける意味も含めて，振り埩の代わ りに表面に発泡スチロール板を浮かせて，振り趎の代替 とその役割について検討した．特にアルコール発醉と酢 酸発醇の影響をみるために，発泡スチロール板を仕込み 後 90 日間浮加せたすのと，仕込み後 20 日目で取り除い たものにっいて実験を行った．経日的なアルコールと酸 生成の結果を, Fig. 2 に示した. アルコール生成は 20 日目で，共に 8.2 8.5\%であった. 20 日目で一方は発 泡スチロール板を取り除いたところ，酶酸発醉は順調に 行われ，45 日目で $2.4 \% ， 90$ 日目では $5.5 \%$ の酸を生 成した. 次に発醉期間中，発泡スチロール板を浮かせた るのは，アルコールの減少は僅かにみられたが，酢酸菌 膜が表面に生育できなかったため，酶酸発醉は行われな かった．前報勇において $5 l$ の小壸を用いて，研究室規 模で同様の実験を行ったところ，アルコールは 20 日目 で共に 7.1 7.3\% 生成し，20日目で一方は発泡スチ ロール板を取り除いたところ，酢酸発醉は順調に行われ たが，発醉期間中発泡スチロール板を浮かせたすのは， 酢酸発蠤は行われなかったことを報告したが，本実験に
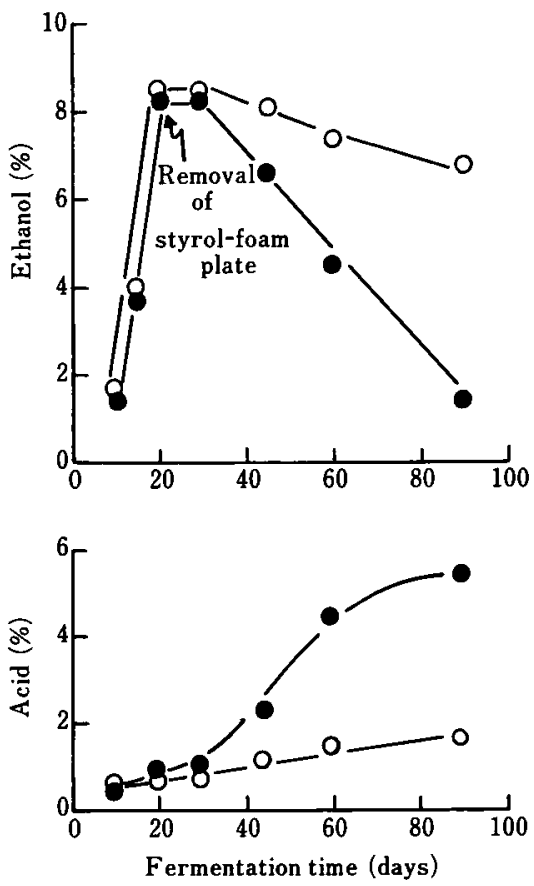

Fig. 2 Effects of styrol-foam plate on the production of ethanol and acid during rice vinegar manufacturing process in a pot

$\mathrm{O}-\mathrm{O}$ With a styrol-foam plate on the surface of the mash throughout the fermentation

- With a styrol-foam plate removed after alcohol fermentation

おいてす同様の結果を示した。

振り懒の代替として，発泡スチロール板を表面に浮か せて，仕込み後 20 日目に取り除いたものは，順調に酢 酸発醉が行われた事より, 酢酸発醉が行われる時期に， 表面から液中に振り趩や蒸米等が落下しない場合は，こ れらを故意に落としてやり，表面に酢酸菌膜が増殖でき る状態を作る必要があることが分った，振り䞻の代替と して発泡スチロール板を使用しても，糖化とアルコール 発醉の工程迄は，十二分に代替できた，このことは振り 埸が壶酢の製造工程の前段階において，重要な役割を果 たしていることを示唆している。これが後半の酢酸発醉 の段階では，酶酸発酵が好気発醉のため，取り除かない 場合には，酢酸発酵を阻害するのは当然のことと思われ る. 振り趐のように製造の後半では, 自然に液中に落下 して，徽生物のフロラの移動を促がす操作を見い出した 
先人の知識は，鰵暎す心゙きちのがある.

\section{5. 微生物添加による影蹱}

盇酢製造においては前述のように，微生物の添加は行 われていないのが多いが，多くの畺の中には正常に発酵 しないものあ見うけられるので，正常発酵を目的に仕込 み時に酵母を添加したすのと，酵母無添加でアルコール 発酵を行わせ，仕込み後 20 日目に眽酸菌を添加して， 発酵へ及ぼす影響について検討した。経日的な成分分析 と微生物測定結果を，Table 3 に示した。仕込み時に 酵母を $10^{3} / \mathrm{ml}$ 添加した A は, アルコールは 10 日目 で $8.4 \%$ を生成した。これを Table 1 の微生物無添加 と比較する上，振り敖有りでは $7 \%$ ，振り敖無しでは $0.7 \%$ 多くアルコールを生成した。 このようにアルコー ル生成が高いため酸生成は遅く，60日目で $1.7 \% ， 90$ 日目では $3.4 \%$ であった. 次に醉母を $10^{5} / \mathrm{m} l$ 添加した B は，アルコールは 10 日目で $10.9 \%$ を生成し，酵母 数も $10^{9} / \mathrm{m} l$ と多かった. その後アルコールの減少は僅 かにみられたが，90日目においても酸生成は $1.7 \%$ で,
アルコール濃度が高かったために，酢酸発酵は殆ど行わ れなかった．次に酵母無添加でアルコール発醉を行わせ， 仕込み後 20 日目に酢酸菌を添加した C については，ア ルコールは 20 日目で $7.3 \%$ を生成し，標準的なアルコ 一ル発醉を示した．酢酸発酵は 30 日目以降行われ，60 日目で $4.3 \% ， 90$ 日目では $5.2 \%$ の酸を生成した。これ を Table 1 の振り敖有りの微生物無添加と比較すると, 酢酸発䤉においては特に添加効果はみられなかった，前 報 ${ }^{3)}$ において $5 l$ の小畐を用いて，研究室規模で同様の 実験を行ったところ，仕込み時に酵母を $10^{3} / \mathrm{m} l$ 添加し たあのは，アルコールは 10 日目で $7.6 \%$ を生成した. 以後，酢酸発醉の開始は僅かに遅れたが，40日目では 醭母無添加と此較して酸生成は殆ど変わらなかった. 次 に醏母を $10^{5} / \mathrm{m} l$ 添加したものは， 5 日目でアルコール は $10.6 \%$ を生成した。 以後，アルコールの減少は僅加 にみられたが，40日目であ䣫酸発酵は行われなかった。 また，酵母無添加でアルコール発酵を行わせ，仕込み後 20 日目に酢酸菌を添加したものは，20日目でアルコー

Table 3 Effects of adding yeast and acetic acid bacteria on the chemical components and microbial counts during rice vinegar manufacturing process in a pot

\begin{tabular}{|c|c|c|c|c|c|c|c|}
\hline \multirow[b]{2}{*}{ Sample } & \multirow{2}{*}{$\begin{array}{l}\text { Fermentation } \\
\text { period (days) }\end{array}$} & \multicolumn{3}{|c|}{ Chemical components } & \multicolumn{3}{|c|}{ Microbial count (viable cells $/ \mathrm{m} l$ ) } \\
\hline & & $\mathrm{pH}$ & $\operatorname{Acid}(\%)^{*}$ & Ethanol (\%) & $\begin{array}{l}\text { Lactic acid } \\
\text { bacteria }\end{array}$ & Yeast & $\begin{array}{l}\text { Acetic acid } \\
\text { bacteria }\end{array}$ \\
\hline \multirow{5}{*}{ A } & 10 & 3.52 & 0.76 & 8.41 & $9.7 \times 10^{8}$ & $4.0 \times 10^{8}$ & - \\
\hline & 20 & 3.40 & 1.08 & 8.30 & $4.1 \times 10^{8}$ & $6.6 \times 10^{7}$ & 1. $3 \times 10^{2}$ \\
\hline & 30 & 3.37 & 1. 24 & 7.95 & 8. $3 \times 10^{7}$ & $6.3 \times 10^{5}$ & $5.7 \times 10^{4}$ \\
\hline & 60 & 3.21 & 1.73 & 6.28 & $<10$ & $4.9 \times 10^{1}$ & $2.0 \times 10^{5}$ \\
\hline & 90 & 3.15 & 3.40 & 2.64 & - & - & $6.8 \times 10^{7}$ \\
\hline \multirow{5}{*}{ B } & 10 & 3.48 & 0.72 & 10.88 & $6.1 \times 10^{7}$ & $4.0 \times 10^{9}$ & - \\
\hline & 20 & 3.41 & 0.97 & 10.25 & $4.5 \times 10^{7}$ & $2.1 \times 10^{8}$ & $1.0 \times 10^{2}$ \\
\hline & 30 & 3.37 & 1.18 & 9.56 & 3. $7 \times 10^{6}$ & $7.3 \times 10^{5}$ & $3.4 \times 10^{8}$ \\
\hline & 60 & 3.32 & 1.46 & 7.28 & $<10$ & $<10$ & $2.6 \times 10^{2}$ \\
\hline & 90 & 3.20 & 1.72 & 6.64 & - & - & 1. $3 \times 10^{2}$ \\
\hline \multirow{5}{*}{$\mathrm{C}$} & 10 & 3. 60 & 0.90 & 1. 20 & $2.5 \times 10^{8}$ & $9.4 \times 10^{3}$ & - \\
\hline & 20 & 3.34 & 1.15 & 7.26 & $4.6 \times 10^{7}$ & $6.3 \times 10^{7}$ & $8.5 \times 10^{3}$ \\
\hline & 30 & 3.28 & 1.47 & 6.68 & $1.0 \times 10^{6}$ & $2.7 \times 10^{3}$ & 1. $3 \times 10^{5}$ \\
\hline & 60 & 3. 20 & 4. 29 & 1.57 & $<10$ & - & $5.9 \times 10^{7}$ \\
\hline & 90 & 3.18 & 5. 23 & 0.30 & - & - & $3.0 \times 10^{3}$ \\
\hline
\end{tabular}

*as acetic acid

A : Added with yeast $\left(10^{3}\right.$ cells per $\left.\mathrm{ml}\right)$ immediately after the mash preparation

$B$ : Added with yeast $\left(10^{5}\right.$ cells per $\mathrm{ml}$ ) immediately after the mash preparation

$C$ : Added with acetic acid bacteria $\left(10^{3}\right.$ cells per $\left.\mathrm{m} l\right)$ after the completion of alcohol fermentation without addition of yeast 
ルは $6.7 \%$ を生成し，以後，酢酸発醉は行われ，40日 目で $5.9 \%$ の酸を生成した事を報告したが，本実験にお いても同様の結果を示した。

仕込み初期のアルコール発醉を，正常に行わせる目的 で酵母を添加したが，添加菌数が多くなるとアルコール 生成が高くなり，酢酸発酵は行われなかった．前報引で 報告したように，理想的な萤酢製造は自然に醅母が增殖 して, アルコール発酔が行われた後，上面の振り数等は 落下して，次に酢酸菌が表面に增殖して酢酸発醉が行わ れることである. 試料 A のように酵母を $10^{3} / \mathrm{m} l$ 添加 して，急激にアルコール生成を行わせ，以後の酢酸発醉 の開始が非常に遅い場合と，徽生物無添加で標準的にア ルコールと酢酸発醉が終了したすのとでは，盇酢中の成 分がどのように製品へ影響するかは，今後の検討課題の 一つであある，自然条件下で行われている夁酢製造にお いて，アルコール発醅が行われない場合は，少量の醉母 添加は必要と思われる．また，酢酸発醉が十分行われる アルコール濃度において，酢酸発醉が行われない場合に は，酶酸菌を添加する必要はあると思われる。

東ら ${ }^{1111}$ は酵母と酢唆菌の培盖液を，一定量仕込み 時に添加して，アルコールと酸生成をみているが，微生 物添加区ではアルコール生成は，1〜2 週問後に 5.8〜8.8 $\%$ に達し，酸生成は 14 日目頃加始まり，微生物添加 か発醇期間の短樎と，生酸で有利であることを報告して いる，著者らと微生物の添加条件は異なるが，本実駼結 果より醉母の添加は，急激にアルコール生成を多くし， 過剩なアルコールは以後の酢酸発醉を阻害することが， 明らかとなった。

以上の結果より，盇酢製造における振り趎と微生物の 関係についてまとめてみると，振り靝を行わない場合に は仕込み直後，靝と蒸米の混合物が浮上して，あたかも 振り畧の役割を果しているように感じるが，前述したよ うに落下菌による表面への細菌とカビ類の増殖は，以後 の発醉に大きく影響すると思われる．振り静は老将敖を 使用しているので，糖化とアルコール発醉中に表面に菌 糸の蓋を形成し，乾懆状態を保つので，落下菌の增殖を 阻止しているものと思われる。葨酢の発醉の初期には， 赹菌の糖化作用により糖分の生成之同時に，乳酸菌が增 殖し $1 \%$ 前後の乳酸が生成される.これが酵母の增殖に よるアルコール生成迄の雑菌の增殖を防いでいると思わ れる，乳酸が生成されると醉母の增殖が始まり，糖化之 アルコール発醉が行われ，アルコールが生成される．了 ルコール生成が終了すると，酷酸菌が増殖し始める．同

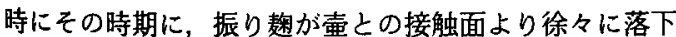

し始め，完全に酢酸菌膜におおわれ，醉母の菌群加ら酢 酸菌群へとフロラが変わる.

乳酸菌と醉母は主として製静中に瞵に含まれ，糖分の 生成之同時に乳酸菌群への移行, 乳酸生成之同時に醉母 菌群へと移行が進む。この間，振り䞮の状態は保たれて いる，糖化，乳酸生成とアルコール発醉中にも，醪中に は酢酸菌は含まれているが，趜菌の菌蓋により酢酸菌の 增殖は抑制されている．菌蓋の落下に伴い，酥酸菌群へ 移行し酶酸発醉加始まる。酢酸菌は恐らく，声穴に住み ついていると推察している．要するに，振り数が微生物 菌群の移行に重要な役割を果たしていることがうかがえ る. フロラの移行は乳酸菌から醂母，さらに酶酸菌へ之 变化している。

最後に振り数の役割についてまとめてみると，落下菌 堌殖の防止，酢酸発酵への適正レベルのアルコール生成， さらに微生物菌群の移行等, 蒙酢製造において重要な役 割を果しているすのと推察する。

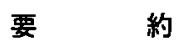

壳酢製造における振り麹の役割について，実際に鹿児 島県姶良郡福山町で，工業生産規模の仕込みを行い検討 した.

（1）振り鏻添加の有無による発酵への影響については， 振り麹有りではアルコール生成及び酢酸発酵は順調に行 われたが，振り靝無しではアルコール生成は早く，生成 量む多く，以後の酢酸発醉の開始が遅れ，発酵期間む長 かった，過剩なアルコールは，酢酸菌に上る酢酸発酵を 阻害することが分った。

（2）振り趐添加の有無による有機酸生成の影響につい ては，酢酸以外の有機酸については，乳酸の含量が一番 多く，振り麹有りの方が振り静無しのものより，乳酸は 多かった。この他に、コハク酸, ピログルタミン酸, ピ ルビン酸, リンコ酸の生成がみられた。

（3）振り麹添加の遅延による発酵への影響については， 振り錮の散布が遅い程アルコール生成が早く，その生成 量も多く，以後の酢酸発醅は順調に行われなかった

（4）振り敖の代替として，発泡スチロール板を表面に 浮かせて，盇酷製造を行った所，仕込み後20日目で取 り除いたものは，順調に酢酸発酵は行われたが，90日 間の発醉期間中，発泡スチロール板を浮かせたものは， 酢酸発酵は行われなかった。

（5）仕込み時に酵母を添加した所，添加菌数が多いと アルコール生成は多く，以後の酢酸発酵は行われなかっ た．酵母無添加でアルコール発酵を行った後，酢酸菌を 
添加して酷酸発醉を行ったものは，無添加と比較して酢 酸発酵に差はみられなかった。

仕込み直後に行われる振り趨は，仕込み初期の急激な アルコール生成を抑えると同時に, 種々のカビや産膜酵 母等の混入防止の役割之, 乳酸菌群から醉母菌群さらに 酢酸菌群へのフロラの推移を司どり，㯰酢製造における 重要な役割を果していることがわかった.

\section{文献}

1）東 邦雄・水元弘二・盛 敏・前田フキ: 鹿工 誌年報, No. 20, 58 (1974).

2）東 邦雄: 䁔協， 76, 456 (1981).

3）小泉幸道・都筑順一・中村勇人・柳田藤治：日食
工誌, 35, 670 (1988).

4）柳田藤治・小泉幸道・ 中里厚実・荒木昌純・芳野 秀敏・若松郁雄 : 酾協, 71, 574 (1976).

5）柳田藤治・小泉幸道・荒木昌純 - 秋山普史 - 石塚 和仁・横森 俊: 醇協, 72, 213 (1977).

6）柳田藤治・小泉幸道: 東京農業大学アイントーフ 研究所研究報告, 1, 33（1980）.

7）柳田藤治・小泉幸道：䁔協，75，854（1980）。

8）伊藤 寛: 䣬協, 73, 200 (1978).

9）海老根英雄：食の科学，63，60（1981）.

10） 円谷悦造・正井博之：醴工，63，211 (1985).

11）東 邦雄・水元弘二・南園博幸・盛敏・前田 フキ : 鹿工誌年報, No. 21, 61 (1975).

（昭和 63 年 7 月 7 日受理） 